\title{
Efficacy of ivermectin, fipronil and their combination against ectoparasites in the Felis catus (Cats)
}

\author{
Malik Muhammad Shehzad ${ }^{1}$, Khurram Ashfaq ${ }^{1}$, Muhammad Saqib ${ }^{1}$, \\ Ghulam Jelani ${ }^{1}$, Muhammad Inamullah Malik ${ }^{2 *}$, Mohammad Noman ${ }^{3}$, \\ Shakeeb Ullah², Muhammad Kamal Shah'², SM Raihan Dilshad ${ }^{2}$ and \\ Muhammad Faheemullah Khan ${ }^{2}$ \\ 1. Department of Clinical Medicine and Surgery, University of Agriculture, Faisalabad-Pakistan \\ 2. Faculty of Veterinary and Animal Sciences, Gomal University, Dera Ismail Khan-Pakistan \\ 3. Department of Epidemiology, University of Veterinary and Animal Sciences, Lahore-Pakistan \\ *Corresponding author's email: malikinamgu@gmail.com \\ Citation \\ Malik Muhammad Shehzad, Khurram Ashfaq, Muhammad Saqib, Ghulam Jelani, Muhammad Inamullah Malik, \\ Mohammad Noman, Shakeeb Ullah, Muhammad Kamal Shah, Syed Raihan Dilshad and Muhammad \\ Faheemullah Khan. Efficacy of ivermectin, fipronil and their combination against ectoparasites in the Felis \\ catus (Cats). Pure and Applied Biology. Vol. 8, Issue 2, pp1564-1570. \\ http://dx.doi.org/10.19045/bspab.2019.80097
}

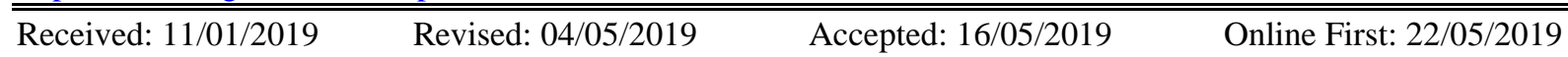

\section{Abstract}

Various skin diseases, allergic and hypersensitivity disorders are caused by ectoparasites. A variety of diseases causing agents are transmitted through ectoparasites. For the control and prevention of ectoparasitic infestations, different antiparasitic agents are used. The present study was designed to analyze the efficacy of ivermectin and fipronil in cats. For this purpose, 40 cats of different age and both sexes infested with ectoparasites were divided into four groups viz A, B, C and D. Cats of groups $\mathrm{A}, \mathrm{B}$ and $\mathrm{C}$ were treated with ivermectin, fipronil, combination of ivermectin and fipronil, respectively, while group $\mathrm{D}$ served as control. At $7^{\text {th }}$ and $15^{\text {th }}$ day of post treatment, cats were examined for the presence of ectoparasites. Three milliliter of blood sample was collected before and post treatment at day 0,7 and 15 aseptically from the jugular vein of each cat in EDTA coated vacutainers and were subjected to hematological analysis. The efficacy of insecticides was statistically analyzed and data obtained from the results. The efficacy percentage of Ivermectin was 60 and 90, fipronil, 80 and 100 while their combination showed 90 and 100 percent efficacy at the day $7^{\text {th }}$ and $15^{\text {th }}$ respectively. WBCs and RBCs were significantly higher at day $15^{\text {th }}$ for group C. While PCV and $\mathrm{Hb}$ concentration were higher for group B at $15^{\text {th }}$ day of study. In case of weight gain group $\mathrm{A}$ and $\mathrm{C}$ showed significant improvement over group $\mathrm{B}$. It is concluded that in case of efficacy and hematology Fipronil and combination form is more effective.

Keywords: EDTA; Felis catus; Hematology; Insecticides

\section{Introduction}

Ectoparasites are a common source of causing skin disorders. Ecotoparasite play a key role in the transmission of various disease in animals especially cause anemia, which is life threatening in weak and young age animals [1]. Hypersensitivity is a disorder resulted in various diseases especially by ectoparasites. Clinical symptoms in cats and dogs are very seldom [2]. Control of ectoparsites like mite, flea and tick was challenge but with introduction of new products like growth regulators and ovicidal product helped to control cat fleas in North America. Ticks infestations in outdoor cats are also 
common [3]. Dermacentor variabilis, Rhipicephalus sanguineus, Ixodes spp. and Amblyomma spp are also common in cats. Two types of mites infest cats, Demodex cati and Demodex gatoi [3]. The most common mites in cats are Cheyletiellablakei. Sarcoptied mitea and notoedre that cause skin diseases. Louse infestation in cat is also very common, the most common lice is Felicola subrostratus [4]. To control different internal and external parasite many veterinary products are available. Among these some are effective against both ecto and endo parasites and fulfill farmer demand for the treatment and prevention of the disease [5]. A drug with the anti-parasitic affect against ecto and endo parasite is Ivermectin used in pets and livestock throughout the world. Fipronil acts as a broad spectrum insecticide which is effective against large number of insects especially fleas, mosquito, lice and ticks in pets. Both Ivermectin and Fipronil are very effective when administered at low rate regarding their pharmaceutical properties.

In Pakistan, certain data regarding ectoparasite and their control in cat is not available. That's why the said work was planned to investigate the important ectoparasite most prevalent in the cats and to measure the effect of ectoparasitic drugs, Ivermectin and Fibronil in cat population used separately and in combination. Different Hematological parameters of the infested cats were investigated.

\section{Materials and methods \\ Experimental anicmals}

Number of cats selected for this study was 40. A selection criterion was based on study of positive infected cats suffering from ectoparasites. Cats were divided equally into $\mathrm{A}, \mathrm{B}, \mathrm{C}$ and $\mathrm{D}$ group. These groups were treated with different antiparasitic drugs, ivermectin was used for group A, fipronil for group $\mathrm{B}$, both fipronil and ivermectin were used for group C and D was a control group.

\section{Drugs to be used}

$250 \mu \mathrm{g} / \mathrm{kg}$ injected subcutaneous as a dose carrying ivermectin $1 \%$ of Ivomec $^{\mathrm{TM}}$ (Merial). Fipronil (25\%) was used as foremost (fipronil spray).

\section{Examination of ectoparasites load}

The cats were examined visually before the start and end of treatment and ectoparasites were calculated as well their location on the body was noted. Thorax, neck, tail, ears and abdomen were examined. Different Ectoparasites were found, therefore 3 classes were made;

Class 1: Low density ( $<10$ ectoparasites)

Class 2: Medium density $(10<$ and $<50)$

Class 3: High density $(50<$ and $<100)$, [6].

\section{Efficacy calculation}

By comparing number of ectoparasites infesting, treatment efficacy was measured before treatment and at the $7^{\text {th }}$ day post treatment. The efficacy of treatment was calculated using the following formula: [7]. Percent efficacy $=$

No. of ectoparasites on control cats -No. of ectoparasites on treated cats / Mean number of ectoparasites on control group Cats x 100 [7]

\section{Collection of blood samples}

$3 \mathrm{ml}$ blood was collected from jugular vein using syringe with hypodermic needle on day 0,7 and 15 of the treatment. Vacutainers having EDTA were used to collect the blood and blood was further used for examination of different blood parameters.

\section{Hematology}

The hematological parameters were defined through laboratory tests like complete blood count using standard procedures.

1. Total Erythrocyte Count [8], Hemocytometer were used to find out erythrocyte count.

2. Total Leukocyte Count [8], the presentation of white blood cells was dark blue to purple with some granularity.

3. Packed cell volume (PCV \%): found out by micro haematocrit process [8].

4. Hemoglobin [8]

4. Hematocrit [9]

Hemoglobin concentration $(\mathrm{Hb} \mathrm{g} / \mathrm{dl})$ was found out by cyano methemoglobin method 
and $540 \mathrm{~nm}$ wave length solution was used in process. Solution consisted of;

$\begin{array}{ll}\text { Distilled water } & 1 \mathrm{~L} \\ \text { Potassium cyanide }(\mathrm{KCN}) & 50 \mathrm{mg} \\ \text { Sodium bicarbonate } & 1.0 \mathrm{gm} \\ \text { Potassium ferric cyanide } & 200 \mathrm{mg}\end{array}$

20 ul blood was taken from each cat and mixed with $5 \mathrm{ml}$ of Drabkin's solution. Color and absorbance developed in the reaction mixture were find out by biochemical analyzer at the rate of $540 \mathrm{~nm}$ and following formula was used to find concentration:

Concentration of $\mathrm{Hb}(\mathrm{gd})=$ absorbance of sample $\mathrm{x}$ concentration of standard / Absorbance of standard

\section{Estimation of anemia}

The cat's blood collected before and after treatment was used to define the anemic status by comparing their hemoglobin level.

\section{General body condition}

Cats were examined physically i.e. general appearance, the weight, feed intake before and after the treatment.

\section{Statistical analysis}

Data generated was calculated with Mean value of ANOVA.

\section{Results}

The study was carried out at the teaching hospital, University of Agriculture, Faisalabad. Forty cats were selected and divided into 4 groups having body weight between 3 to $4 \mathrm{~kg}$ (A, B, C and D). $1 \%$ Ivermection was used subcutaneously at the rate of $250 \mathrm{ug} / \mathrm{kg}$ in Group A. Fibronil spray was used in Group B. In group $\mathrm{C}$ both ivermectin and fibronil combination was used with 15 days interval. The hair coat of cats' infested parts got slightly wet when fipronil sprayed on them. The D was a control Group and no drug was used in this group. Treatment in all 3 groups was repeated with the interval of 15 days. On day 0,7 and 15 blood was collected and hematology tests were performed on fresh blood samples. The table show the whole mean value of red blood cells, hemotocrit, on day 0,7 and 15 and also drug efficacy recorded after every treatment.

\section{Efficacy of ivermectin}

The efficacy of Ivermectin was calculated according to the Abbot's formula. Ectoparasites were counted on the control animals. Ectoparasites count was done on the particular areas like ear, neck and abdomen. The mean number of parasites found in these areas was 100 while the mean number of ticks found on the animals of group B on day 7 was 60 . The efficacy calculated on day 7 was $60 \%$. The mean number of ticks found on the animals at day 15 was 10 representing efficacy of $90 \%$.

\section{Efficacy of fipronil}

The efficacy of fipronil was calculated according to the Abbot's formula [7]. Ectoparasites were found on control animals. They were counted on particular areas of the body like tail, thighs, neck and abdomen. The mean number of ectoparasites found in these areas was 100 while the mean number of ectoparasites found on the animals of group B on the $7^{\text {th }}$ day was 20 , showing $80 \%$ efficacy. While the mean number of ectoparasites found on the animals at the day 15 was 0 , showing $100 \%$ efficacy.

\section{Efficacy of ivermectin + fipronil}

The efficacy of the antiparasites was calculated by the Abbot's formula. Ectoparasites were counted on the control animals. Ectoparasites were counted on particular areas like tail, thighs, neck and abdomen. The mean number of ectoparasites found in these areas was 100 while the mean number of ectoparasites found on the animals of group $\mathrm{C}$ on day 7 was 10 , showing $90 \%$ efficacy. The mean number of ectoparasites found on the animals at day 15 was 2 . The efficacy calculated at day 15 was $100 \%$.

\section{Erythrocyte count}

In the present study an increasing trend was observed (Table 1). On the day 0 all the treated groups were commonly nonsignificant. At $7^{\text {th }}$ day there was valued increase in the erythrocyte count. Group A (IVR), group B (Fipronil), group C (IVR+Fipronil) showed significantly increased at day $7^{\text {th }}$. The erythrocyte count of group B and C were significant when 
compared to the control group. After first treatment, at day $7^{\text {th }}$ group $\mathrm{C}$ showed preference over its counterpart. The same trend was observed on day 15 . The results of the treatment for RBC's at $15^{\text {th }}$ day were mutually significant. The highest increase was observed in group $\mathrm{C}$.

\section{Total leukocyte count}

All the treatments for WBCs was nonsignificant at day 0 . In the present study an increasing style was also observed in case of total leukocyte count. Group A (IVR), Group B (fipronil) and at the $7^{\text {th }}$ day control and fipronil showed non-significant for WBCs while other group Ivermectin+Fipronil were mutually significance, the highest values for the total leukocyte count was observed in group C. All the groups showed significant increase in WBCs at day 15. The highest increase in WBCs was observed in Groups B and C at day 15 i.e. it statistically showed importance over its counterparts. The results were somewhat different from the $1^{\text {st }}$ interval (Table 1).

\section{Pack cell volume}

In the present study increasing trend was found in case of pack cell volume (Table 1). At day 0 of the trial, all the results were non-significant to each other. The two groups $\mathrm{D}$ and $\mathrm{C}$ were significant with each other. While at day 7, Group B and C treatment were non-significant with each other. At the 15 day of the treatment the results found to be non-significant for group B (Ivermectin) and group D (Ivermectin+Fipronil). On the other hand statistically significant for group $\mathrm{C}$ and group D (Ivermectin+Fipronil). The highest increase in Pack Cell Volume was observed in Group B and D at day 15.

\section{Hemoglobin estimation}

At day 0, all the treatment results among these groups found to be non-significant, Treatment result at day 7 found to be significant for Ivermectin and nonsignificant for the rest of groups. The treatment results found significant at the day 15, for Ivermectin+Fipronil and fipronil, on the other hand non-significant for Ivermectin, fipronil and Ivermectin+ Fipronil. The highest value was observed in group B and C at the day 15 (Table 1).

\section{Weight gain}

In this study an increasing trend was observed in case of weight gain. Body weight of the cats was calculated at day 0 and at day 15 . These were compared with the weights of the animals of control group. In terms of weight gain, an increasing trend was observed in Group C which was treated with both IVR and fipronil. Group A and Group $C$ treatments found to be statistically non-significant, group A (Ivermectin) and Group B (Fipronil) were also nonsignificant, while Group B (Fipronil) and Group $\mathrm{C}$ were statistically preference over its counterparts. All treatment groups except Group B showed significant increase when compared to the control group. (Table 2).

The treatment results found significant only for Ivermectin+ Fipronil and fipronil.

\section{Discussion}

To find out the efficiency of antiparasitic drug ivermectin (Ivomec) and fipronil (frontline spray) against ectoparasite in cat a study was conducted. Ivermectin was given subcutaneously to 10 cats of group A at the rate of $250 \mathrm{mcg} / \mathrm{kg}$ body weight, gave 60 and $90 \%$ efficacy on the $7^{\text {th }}$ and $15^{\text {th }}$ day respectively after medication. In this study, it was found that when ivermectin and fipronil were given by parentral route was more effective.

$1 \%$ ivermectin $\mathrm{w} / \mathrm{v}$ concentration in Ivomec. Ivermectin is very effective against many endo and ecto parasites even at very low dose. Cats were given $250 \mathrm{mcg} / \mathrm{kg} / \mathrm{s} / \mathrm{c}$, at $15^{\text {th }}$ day $90 \%$ efficacy was achieved. In that study it was found that the ivermectin is not only effective but also very safe drug to control ectoparasite in cats. A single s/c dose of ivermectin is sufficient to control ectoparasites $[10,11]$. 100\% efficacy was shown by fipronil to control ectoparasites. 
Table 1. The mean RBCs, WBCs, PCVs and mean values of $\mathrm{Hb}$ at day 0,7 and 15

\begin{tabular}{|c|c|c|c|c|c|c|c|c|c|c|c|c|}
\hline & \multicolumn{4}{|c|}{ At day 0} & \multicolumn{4}{|c|}{ at day 7 th } & \multicolumn{4}{|c|}{ at day 15th } \\
\hline & RBCs & WBCs & PCV & HB & RBCs & WBCs & PCV & HB & RBCs & WBCs & PCV & HB \\
\hline Group & $\begin{array}{c}\text { Mean } \pm \\
\text { SE }\end{array}$ & $\begin{array}{c}\text { Mean } \pm \\
\text { SE }\end{array}$ & $\begin{array}{c}\text { Mean } \pm \\
\text { SE }\end{array}$ & $\begin{array}{c}\text { Mean } \pm \\
\text { SE }\end{array}$ & $\begin{array}{c}\text { Mean } \pm \\
\text { SE }\end{array}$ & $\begin{array}{c}\text { Mean } \pm \\
\text { SE }\end{array}$ & $\begin{array}{c}\text { Mean } \pm \\
\text { SE }\end{array}$ & $\begin{array}{c}\text { Mean } \pm \\
\text { SE }\end{array}$ & $\begin{array}{c}\text { Mean } \pm \\
\text { SE }\end{array}$ & $\begin{array}{c}\text { Mean } \pm \\
\text { SE }\end{array}$ & $\begin{array}{c}\text { Mean } \pm \\
\text { SE }\end{array}$ & $\begin{array}{c}\text { Mean } \pm \\
\text { SE }\end{array}$ \\
\hline Ivermectin (A) & $\begin{array}{l}5.62 \pm \\
0.118 \\
\end{array}$ & $\begin{array}{c}11.48 \pm \\
0.306\end{array}$ & $\begin{array}{c}24.47 \pm \\
0.668\end{array}$ & $\begin{array}{c}10.06 \pm \\
0.228\end{array}$ & $\begin{array}{l}6.33 \pm \\
0.098\end{array}$ & $\begin{array}{c}12.75 \pm \\
0.168\end{array}$ & $\begin{array}{c}26.25 \pm \\
0.813\end{array}$ & $\begin{array}{c}11.00 \pm \\
0.211\end{array}$ & $\begin{array}{l}7.33 \pm \\
0.090\end{array}$ & $\begin{array}{c}14.02 \pm \\
0.157\end{array}$ & $\begin{array}{c}28.70 \pm \\
0.574\end{array}$ & $\begin{array}{c}10.08 \pm \\
0.194\end{array}$ \\
\hline Fipronil & $\begin{array}{l}5.54 \pm \\
0.118 \\
\end{array}$ & $\begin{array}{c}11.37 \pm \\
0.309 \\
\end{array}$ & $\begin{array}{c}24.01 \pm \\
0.854 \\
\end{array}$ & $\begin{array}{c}10.03 \pm \\
0.195 \\
\end{array}$ & $\begin{array}{l}5.85 \pm \\
0.134 \\
\end{array}$ & $\begin{array}{c}11.58 \pm \\
0.287 \\
\end{array}$ & $\begin{array}{c}24.05 \pm \\
0.813\end{array}$ & $\begin{array}{c}10.15 \pm \\
0.206\end{array}$ & $\begin{array}{l}6.12 \pm \\
0.118 \\
\end{array}$ & $\begin{array}{c}17.92 \pm \\
2.180\end{array}$ & $\begin{array}{c}24.17 \pm \\
0.900 \\
\end{array}$ & $\begin{array}{c}12.40 \pm \\
0.210 \\
\end{array}$ \\
\hline (B) & $\begin{array}{l}5.85 \pm \\
0.128\end{array}$ & $\begin{array}{c}11.46 \pm \\
0.289 \\
\end{array}$ & $\begin{array}{c}24.47 \pm \\
0.668\end{array}$ & $\begin{array}{c}10.08 \pm \\
0.228\end{array}$ & $\begin{array}{l}7.07 \pm \\
0.046\end{array}$ & $\begin{array}{c}14.12 \pm \\
0.083\end{array}$ & $\begin{array}{c}24.05 \pm \\
0.889\end{array}$ & $\begin{array}{c}09.82 \pm \\
0.287\end{array}$ & $\begin{array}{l}8.42 \pm \\
0.110\end{array}$ & $\begin{array}{c}15.23 \pm \\
0.100\end{array}$ & $\begin{array}{c}28.79 \pm \\
1.363 \\
\end{array}$ & $\begin{array}{c}11.36 \pm \\
0.986\end{array}$ \\
\hline $\begin{array}{l}\text { Ivermectin+ } \\
\text { Fipronil (C) }\end{array}$ & $\begin{array}{c}5.62 \pm \\
0.118\end{array}$ & $\begin{array}{c}11.53 \pm \\
0.282\end{array}$ & $\begin{array}{c}24.62 \pm \\
0.608\end{array}$ & $\begin{array}{c}10.16 \pm \\
0.198\end{array}$ & $\begin{array}{l}5.67 \pm \\
0.116\end{array}$ & $\begin{array}{c}14.12 \pm \\
0.298\end{array}$ & $\begin{array}{c}27.21 \pm \\
0.799\end{array}$ & $\begin{array}{c}10.07 \pm \\
0.222\end{array}$ & $\begin{array}{c}5.61 \pm \\
0.149\end{array}$ & $\begin{array}{c}11.55 \pm \\
0.283\end{array}$ & $\begin{array}{c}24.56 \pm \\
0.696\end{array}$ & $\begin{array}{c}13.35 \pm \\
0.164\end{array}$ \\
\hline
\end{tabular}

Same letters having $P$. value less than 0.05 i.e. non-significance

Table 2. At day 15 mean of weight gain

\begin{tabular}{|c|c|}
\hline Group & Mean \pm SE \\
\hline Ivermectin & $71.40 \pm 0.414 \mathrm{~A}$ \\
\hline Fipronil & $70.77 \pm 0.386 \mathrm{~B}$ \\
\hline Ivermectin + Fipronil & $72.20 \pm 0.485 \mathrm{C}$ \\
\hline Control & $69.93 \pm 0.389 \mathrm{D}$ \\
\hline
\end{tabular}

Same letter having $P$-value less than 0.05 are non-significant 
The actual efficacy of ivermectin against ticks was found out by injecting multiple dose of ivermectin subcutaneously to calves at rate of $200 \mathrm{mcg} / \mathrm{kg}$ which resulted satisfactory reduction in ticks [12]. Efficacy of ivermectin against mange and gastrointestinal nematodes was found [13]. After 2 weeks of treatment with ivermectin scabies reduced. The scabies was also reduced within 2 weeks and some species were eliminated within 1 week of treatment. The three types of mature cat fleas sensitivity to fibronil spray was done by a study to find out effect on fleas mortality and their eggs production and found that $99.5 \%$ efficacy on egg production and adult fleas mortality [14]. In another study frontline spray used in dog instead of cats [15]. In a study to find long lasting effect of ivermectin against the dogs' ticks. He was found a better efficient result against ticks of dogs [16]. Another study was done to find out the effect of ivermectin on ecto parasite and efficacy was $100 \%$ [17].

\section{Conclusion}

In all above studies result varies because parasites population, management level and environmental conditions were different. Our work was planned to measure the effect of ectoparasitic drugs including Ivermectin and Fibronil in cats' population, used separately and in combination. Different Hematological parameters of the infested cats were investigated. The efficacy of antiparasitic drugs calculated on day 7 and 15 showed that fipronil and its combination with ivermectin have preference over ivermectin alone. Nearly same fashion was observed in hematological and other examined parameters. These results are similar to some and different from other previous studies. Further work on this aspect also advised because these results may be varied due to external factor.

\section{Authors' contributions}

Conceived and designed the experiments: K Ashfaq \& MM Shehzad, Performed the experiments: MM Shehzad \& G Jelani, Analyzed the data: S Ullah \& SR Dilshad, Contributed reagents/ materials/ analysis tools: M Saqib, MF Khan \& MK Shah, Wrote the paper: MI Malik \& M Noman.

\section{References}

1. Karema ME (2012). Investigation on some internal parasites affecting stray dogs and cats. Alex J Vet Sci 35 (1): 211-219.

2. Araujo FR, Silva MP, Lopes AA, Ribeiro OC, Pires PP, Carvalho CM, Balbuena CB, Villas AA \& Ramos JK (1998). Severe Cat flea infestation of dairy calves in Brazil. Vet Parasitol 80: 83-86.

3. Blagburn BL \& Dryden MW (2009). Biology, treatment, and control of flea and tick infestations. Vet Clin North Am Small Anim Pract 39(6): 11731200.

4. Akucewich LH, Philman K, Clark A, Gillespie J, Kunkle G, Nicklin CF \& Greiner EC (2002). Prevalence of ectoparasites in a population of feral cats from north central Florida during the summer. Vet Parasitol 109: 129139.

5. Kvaternick V, Kellermann M, Knaus M, Rehbein S \& Rosentel J (2014). Pharmacokinetics and metabolism of eprinomectin in cats when administered in a novel topical combination of fipronil, methoprene, eprinomectin and praziquantel. Vet Parasitol 202: 2-9.

6. Otranto D, Traversa D, Milillo P, Luca FD \& Stevens J (2005). Utility of mitochondrial and ribosomal genes for differentiation and phylogenesis of species of gastrointestinal bot flies. $J$ Econ Entomol 98(6): 2235-2245.

7. Abbott WS (1987). Abbott's formulaA method of computing the effectiveness of an insecticide. $J \mathrm{Am}$ Mosq Control Ass 3(2): 302-303.

8. Benjamin MM (1978). Outline of Veterinary Clinical Pathology, $3^{\text {rd }}$ Ed. The Iowa State Univ. Press, Ames, Iowa, USA.

9. Cole PV \& Evans P (1972). Simple hemoglobin estimation. A comparison 
of available apparatus. Anesthesia 27: 76-80.

10. Megnano I, Partoutomo S \& Stevenson $P$ (1986). Comparison of ivermectin and Asuntol in the control of mange in goats due to sarcoptes scabiei. Penyak it Hawan Indonesia 18: 58-62.

11. Kutzer E, Presol H, Kohler E \& Lowenstain M (1990). Simultaneous treatment of Hypoderma bovis and Faciola hepatica infestation with ivomec. F Wien Tiera Mona 77: 147152.

12. Pegram RG \& Lemche J (1985). Observation on the efficacy of ivermectin in the control of Cattle ticks in Zambia. Vet Rec 117(21): 551-4.

13. Gill BS, Singh J, Singh A, Kherha SS \& Hussain O (1989). Efficacy of ivermectin against mange and gastrointestinal nematodes of buffalo. Vet Parasitol 31: 141-147.

14. Payne PA, Dryden MW, Smith W \& Ridley RK (2001). Effect of $0.29 \%$ w/w fipronil sprey on adult flea, Ctenocephalides felis (Bouche), strains infecting cats. Vet Parasitol 102: 331340.

15. Pollmeier M, Pengo G, Jeanine P \& Soll M (2002). Evaluation of the efficacy of fipronil Formulations in the treatment and control of bitting lice, Trichodectescanis (De Geer, 1778) on dogs. Vet Parasitol 107: 127-136.

16. Venco L, McCall JW, Guerrero J \& Genchi C (2004). Efficacy of longterm monthly administered of ivermectin on the progress of naturally acquired heartworm infections in Dogs. Vet Parasitol 124: 259-268.

17. Ramzan M, Khan MS, Avais M, Khan JA, Pervez K \& Shehzad W (2008). Prevalence of Ectoparasites and comparative efficacy of Different drugs against tick infestation in Cattle. J Anim Pl Sci 18(1):17-19. 